\title{
Analysis of the frequency of microsatellite instability and p53 gene mutation in splenic marginal zone and MALT lymphomas
} M Sol Mateo, M Mollejo, R Villuendas, P Algara, M Sánchez-Beato, B Martinez-Delgado,
P Martínez, M A Piris
Splenic marginal zone lymphoma (SMZL) is a well defined clinicopathological entity included in the revised European American lymphoma (REAL) classification. ${ }^{1}$ However, studies performed to date on the molecular and genetic features of this tumour have failed to identify changes that are specific to this neoplasm. A hypothetical marginal zone origin has been suggested for SMZL, based on the existence of a prominent marginal zone differentiation in splenic sections, which gave rise to its original description. ${ }^{23}$ This morphological phenomenom led to the supposition that this tumour originated from splenic marginal zone cells, and it was thought to be associated with other marginal zone lymphomas arising in extranodal locations, such as those originating in mucosa associated lymphoid tissue (MALT). ${ }^{24}$ The relation between MALT and SMZL lymphomas has remained controversial, because different studies have reached contradictory conclusions on the existence of common genetic alterations. ${ }^{5-8}$ Although it is now commonly accepted that MALT lymphomas originate in marginal zone lymphoma cells, definite evidence has yet to be supplied for SMZL. ${ }^{9-11}$

Microsatellite instability is a type of genomic instability frequently detected in many types of human tumours. ${ }^{12}{ }^{13}$ It is expressed as differences in the banding patterns of polymerase chain reactions (PCR) amplified DNA from tumour cells versus normal cells at various microsatellite loci. Microsatellite instability was first reported as tumour specific in hereditary non-polypoid colorectal cancer, ${ }^{13-15}$ and sporadic colon cancer. ${ }^{1316}$ In hereditary nonpolypoid colorectal cancer, this genetic instability apparently results from inherited and somatic mutations in mismatch repair genes (hMSH2, hMLH1, hPMS1 and hPMS2). ${ }^{17-21}$ More recently, it has been shown to occur at different frequencies in several other types of tumour. ${ }^{22-24}$ Different studies of the frequency of microsatellite instability in lymphoproliferative disorders have shown this to be an exceptional finding, with the exclusive exception of MALT lymphomas, where microsatellite instability has been identified in up to $52.5 \%$ of patients. ${ }^{25-31}$

On the other hand, p53 mutation is one of the most common genetic alterations in human malignancies, contributing to tumour development and progression. ${ }^{32}$ The frequency of p53 mutation in lymphoid disorders varies from $5 \%$ to $42 \% .{ }^{33}$ In non-lymphoid tumours, most of
Accepted for publication 16 June 1998

\begin{abstract}
Keywords: splenic marginal zone lymphoma; mucosa associated lymphoid tissue lymphoma; p53; microsatellite instability with the mechanisms of tumorigenesis. (F Clin Pathol: Mol Pathol 1998;51:262-267)
\end{abstract}

Correspondence to: Dr Piris.

email: mpiris@cht.es 
the series agree, in that microsatellite instability and p53 mutations are present as mutually exclusive genetic events. ${ }^{35}$ Nevertheless, in MALT lymphomas, an association between both phenomena was found in a previous study. ${ }^{31}$

We are not aware of any study that has been conducted to date on microsatellite instability in SMZL, and the studies performed on the frequency of p53 gene mutations in this tumour type have not provided uniform findings, because the results vary from $0 \%$ to $40 \%{ }^{37-39}$ With the aims of exploring the frequency of both phenomena in SMZL, and of comparing these findings with those obtained in MALT lymphomas, we carried out a comprehensive study on a group of 42 patients, composed of 20 patients with SMZL and 22 patients with MALT lymphomas.

Our results indicate that microsatellite instability is not a frequent molecular feature of SMZL, and could support the hypothesis of different tumorigenic mechanisms for MALT and SMZL lymphomas.

\section{Materials and methods \\ TISSUE SAMPLES}

This study comprised forty two patients. They were obtained from the routine files of the Department of Pathology of Virgen de la Salud Hospital, Toledo, Spain. The group studied included 20 patients with SMZL diagnosed from splenectomy specimens. These patients were diagnosed on the basis of the criteria established by Isaacson and colleagues ${ }^{1140}$ and Mollejo et al. ${ }^{9} 41$

The group studied also included 22 patients with MALT lymphomas (20 gastric, one small-intestinal and one pulmonary), histologically composed of small cells (10 patients), large cells with a peripheral small cell component (eight patients), and large cells (four patients)

MALT lymphomas were categorised according to standard criteria following morphological, immunohistochemical, and molecular studies. ${ }^{1}$ The large B cell lymphomas included within this group either had a contiguous MALT small cell component, or were large cell tumours presenting exclusively in a mucosal location, with a bcl2 negative ${ }^{-}$immunophenotype. ${ }^{42}$

CONTROL DNA SAMPLES

Non-malignant DNA for each patient with SMZL was obtained from oral swabs. For patients with MALT lymphomas, nonmalignant DNA was obtained from bone marrow smears without tumour infiltration, or from microdissected non-malignant areas in their surgical specimens.

DNA ISOLATION

Frozen tissue was available from 40 patients and paraffin wax embedded tissue was available from the other two patients. Before DNA extraction, morphological analysis of the blocks confirmed that most (more than half) of the tissue was composed of malignant cells. Fresh frozen tissue was treated with buffer, sodium dodecyl sulphate (SDS), and protein- ase $\mathrm{K}$, followed by phenol/chloroform extraction and precipitation with ethanol, according to standard procedures. Paraffin wax embedded tissue sections were dewaxed in xylene and hydrated with ethanol. The samples were air dried, incubated with buffer $(50 \mathrm{mM}$ Tris, pH 8.5, 1 mM EDTA, 0.5\% Tween 20) and heated for 10 minutes in a microwave oven.

Normal DNA from bone marrow smears without infiltration was obtained according to the protocol described by Fey et al. ${ }^{43}$

Oral swabs were incubated overnight in double distilled $\mathrm{H}_{2} \mathrm{O}$ at $37^{\circ} \mathrm{C}$, centrifuged, and treated with SDS and proteinase $\mathrm{K}$.

\section{IMMUNOSTAINING}

Immunohistochemical examination was performed in all cases (SMZL and MALT) on formalin fixed, paraffin wax embedded tissue. Immunohistochemical staining for $\mathrm{p} 53$ protein was carried out using the DO7 antibody (Novocastra, Newcastle Upon Tyne, UK) and procedures that have been described previously. ${ }^{44}$ Specimens were considered to be positive if most malignant cells showed distinct p53 nuclear reactivity.

ANALYSIS OF MICROSATELLITE INSTABILITY

Seven microsatellite tetranucleotide repeat markers, mapping to different chromosomes were used, namely: D2S1360, D3S2432, D4S1627, D6S474, D7S1824, D9S934, and D17S1290. Primers used to amplify each locus were obtained from Research Genetics (Huntsville, Alabama, USA). Only tetranucleotide repeats were selected, given that previous studies on microsatellite instability in human cancer have shown that these are more informative than others. ${ }^{45}$

Each microsatellite repeat was amplified using the polymerase chain reaction (PCR). PCR reactions were performed in a final volume of $20 \mu \mathrm{l}$ containing $50-100 \mathrm{ng}$ of DNA template, $10 \mathrm{pmol}$ of each primer, $200 \mu \mathrm{mol} / 1$ dNTPs, $1 \mu \mathrm{Ci} \alpha{ }^{32} \mathrm{PdCTP}$, and $1 \mathrm{U}$ of Taq polymerase (Boehringer Mannheim, Mannheim, Germany). Thirty cycles were performed, each consisting of 30 seconds at $94^{\circ} \mathrm{C}$. Annealing temperatures ranged from $55^{\circ} \mathrm{C}$ to $57^{\circ} \mathrm{C}$ and 30 seconds at $72^{\circ} \mathrm{C}$, using a Perkin Elmer 2400 GeneAmp PCR system. When DNA was extracted from paraffin wax embedded tissues, 35 PCR cycles were performed.

The products of the PCR reactions were mixed with an equal volume of formamide loading buffer (95\% formamide, $20 \mathrm{mM}$ EDTA, 0.05\% bromophenol blue, and 0.05\% xylencyanol), and were then denatured at $95^{\circ} \mathrm{C}$ for five minutes, and cooled on ice. Approximately $2 \mu \mathrm{l}$ of each sample was loaded on to a

Table 1 Frequency of microsatellite instability and p53 mutations

\begin{tabular}{lll}
\hline & $M I N+$ & $m t p 53$ \\
\hline SMZL & $0 / 14$ & $2 / 20$ \\
Total MALT & $5 / 20$ & $1 / 22$ \\
Small cell MALT & $2 / 9$ & $0 / 10$ \\
Large cell MALT & $3 / 11$ & $1 / 12$ \\
p value & 0.05572 & 0.46341
\end{tabular}

MIN, microsatellite instability; mt: mutant p53 gene. 


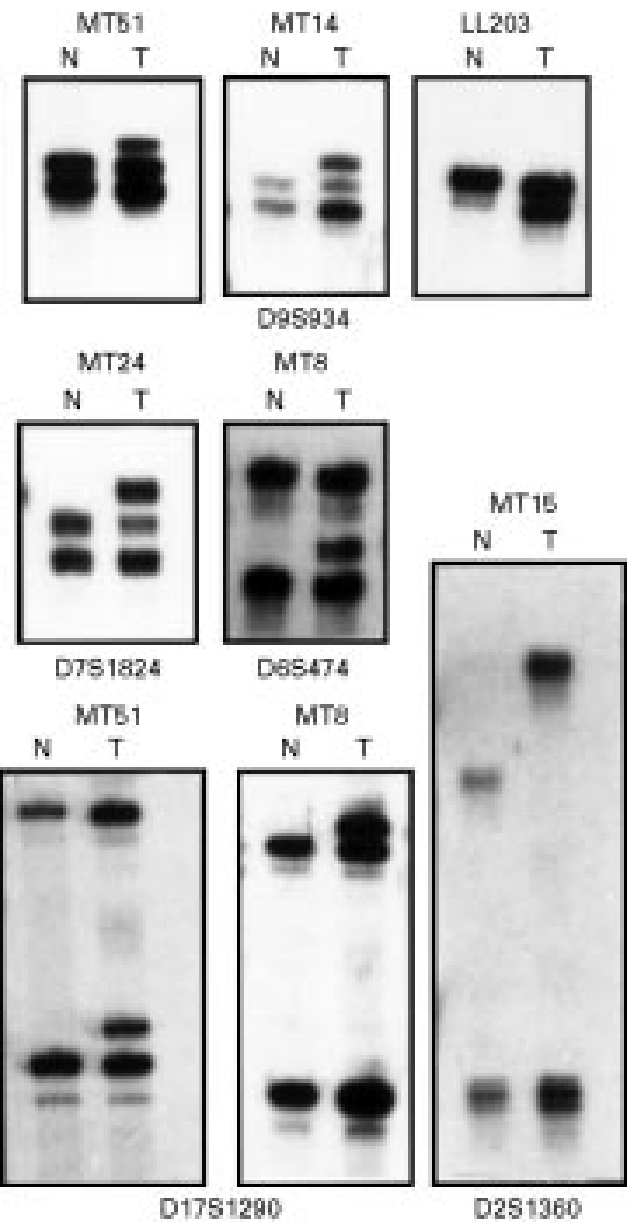

Figure 1 Representative examples of microsatellite analysis in paired normal $(N)$ and tumour $(T)$ samples from SMZL (case LL203) and MALT lymphomas (cases MT51, MT14, MT24, MT8, and MT15). The five markers tested showed at least one case with microsatellite instability. Alterations were found most freqently at the D9S934 locus. In each of the examples shown here, the tumour samples contained extra bands compared with control DNA.

$6 \%$ denaturing polyacrylamide gel containing $7 \mathrm{M}$ urea. Gels were fixed in $10 \%$ acetic acid, air dried, and exposed to $x$ ray films.

SINGLE STRAND CONFORMATION POLYMORPHISM (SSCP) ANALYSIS

To detect p53 gene alterations, we analysed p53 exons $5-8$ by PCR-SSCP. The p53 primer

Table 2 Microsatellite alteration frequency

\begin{tabular}{lllllllll}
\hline Cases & Diagnosis & D2S1360 & D3S2432 & D4S1627 & D6S474 & D9S934 & D17S1290 & D7S1824 \\
\hline MT15 & MALT & + & - & - & + & + & - & + \\
LL159 & MALT & - & - & - & - & + & - & - \\
MT24 & MALT & - & - & - & - & - & - & + \\
MT8 & MALT & - & - & - & + & - & + & - \\
MT14 & MALT & - & - & + & - & + & - & - \\
MT51 & MALT & - & - & - & - & + & + & - \\
MT53 & MALT & + & - & - & - & + & - & - \\
LL179 & SMZL & - & - & - & + & - & - & - \\
LL203 & SMZL & - & - & - & - & + & - & -
\end{tabular}

Table 3 List of cases with p53 mutation, showing the type of mutation

\begin{tabular}{llllll}
\hline Case & Diagnosis & Codon & Exon & Nucleotide change & $\begin{array}{l}\text { Amino acid } \\
\text { change }\end{array}$ \\
\hline LL241 & SMZL & 245 & 7 & GGC $\rightarrow$ AGC & Gly $\rightarrow$ Ser \\
LL201 & SMZL & 272 & 8 & GTG $\rightarrow$ CAC & Val $\rightarrow$ Met \\
MT14 & MALT & 158 & 5 & CGC $\rightarrow$ CAC & Arg $\rightarrow$ His \\
\hline
\end{tabular}

technique and the SSCP procedure were performed according to the methods described by Villuendas et $a l^{44}$

DIRECT SEQUENCING

Sequences of samples in which PCR-SSCP analysis showed shifts in mobility were confirmed by direct sequencing with an automated ABI PRISM 310 DNA sequencer genetic analyser (Perkin Elmer, Norwalk, Connecticut, USA) according to the manufacturer's instructions.

p53 mutation data in cases MT14, LL144 have already been published. ${ }^{37} 44$

\section{STATISTICAL ANALYSIS}

Fisher's exact test was used to compare frequencies in $2 \times 2$ tables.

\section{Results}

MICROSATELLITE INSTABILITY

A total of 14 SMZL and 20 MALT lymphomas were investigated for the presence of microsatellite instability. All samples were tested at seven microsatellite loci. Simple repetitive DNA sequences were amplified by PCR, thereby permitting the comparison of polymorphic parental alleles in the DNA of normal and malignant samples. Microsatellite mutations were identified as extra bands in the tumour sample DNA lanes that were not present in paired normal DNA lanes. To decrease the probability of detecting background mutations, only tumours showing mobility shifts of more than one microsatellite marker were scored positive for microsatellite instability. ${ }^{25}{ }^{46}$ Specimens with microsatellite instability were confirmed by repeating the PCR analysis.

Table 1 summarises the results and representative cases are shown in fig 1 . In the 14 patients with SMZL lymphoma analysed for microsatellite instability, only two showed a shift in the size of one microsatellite locus (table 2 ). The other patients did not have any mobility abnormalities, so that all of the patients with SMZL studied were considered not to have microsatellite instability (table 1) However, seven of the 20 patients with MALT lymphomas had microsatellite alterations. Only five of 20 of the patients with MALT contained two or more microsatellite alterations (one large cell, two composed of areas of small and large cells, and two small cell MALT) (tables 1 and 2). The microsatellite marker where alterations were identified most frequently was D9S934 (table 2).

Statistical analysis of the frequency of microsatellite instability in MALT and SMZL lymphomas showed a trend towards significance $(p=0.05572)$, which is probably a result of the small size of the sample.

DETECTION OF p53 GENE MUTATION

p53 mutations in exons 5-8 were analysed by PCR-SSCP (fig 2). PCR products showing abnormal SSCP patterns were analysed by a direct sequencing technique, to determine the nature of the mutation and the codon involved (table 3 and fig 3). To exclude the possibility 


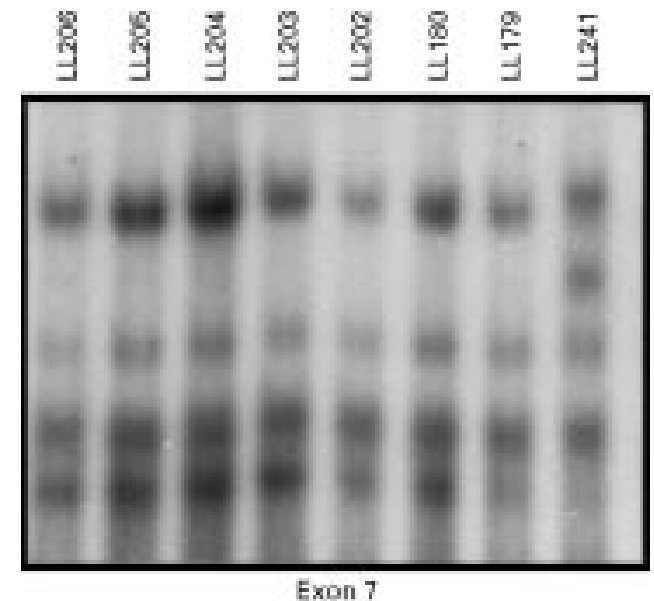

Figure 2 Mutational analysis by PCR-SSCP of the p53 gene in a patient with SMZL (case LL241). SSCP shows anomalous emigration of LL241.

that base changes detected in tumour samples could be caused by polymorphism or germline mutations, genomic DNA from each patient was sequenced.
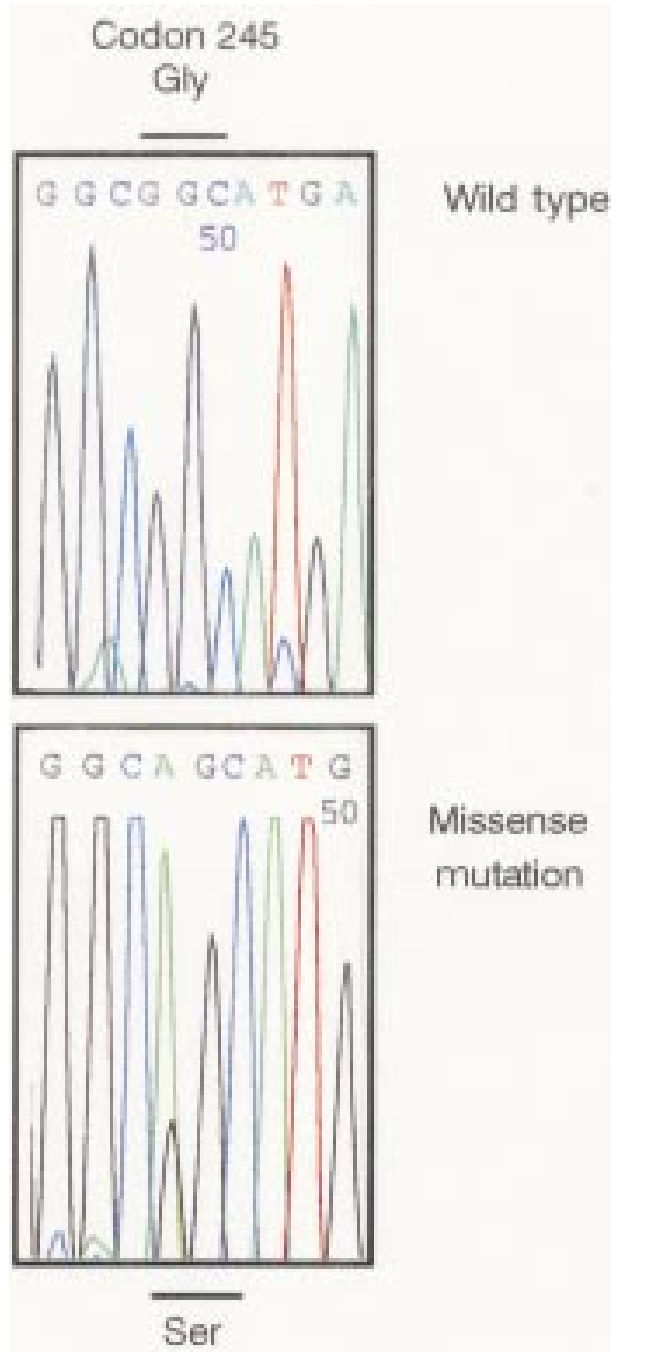

Figure 3 Sequencing of exon 7 from the p53 gene in a patient with SMZL (case LL241). DNA sequencing of the sense chain showing a single base transition in codon 245 of tumour DNA that produces a heterozygous missense mutation (GGC (Gly) $\rightarrow A G C$ (Ser)).
Two of the 20 SMZL lymphomas studied for p53 alterations showed p53 mutations (tables 1 and 3 ). Both were low grade tumours presenting indolent clinical behaviour, and were composed mainly of small cells, although they also had scattered larger cells, a common feature in SMZL histology. In both tumours a high level of p53 expression was detected by immunohistochemistry. The changes found in both specimens were missense mutations in exon 7 (case LL241) (fig 3) and exon 8 (case LL201) (table 3).

One of the 22 MALT lymphomas showed p53 mutations. This patient (case MT14) had a gastric large B cell lymphoma with peripheral areas of a small cell MALT-type component. (tables 1 and 3 ). This tumour had a monoallelic p53 mutation in codon 158 $(\mathrm{CGC} \rightarrow \mathrm{CAC})$, producing a shift from Arg to His. Immunohistochemical analysis of this tumour showed an increase in p53 nuclear accumulation.

Patients LL191, LL211 (MALT lymphomas) and LL144 (SMZL) exhibited polymorphism in codon 213 of exon 6.

Immunohistochemical analysis showed p53 nuclear stabilisation in all three specimens with p53 gene mutations. In addition, two SMZL and three MALT lymphomas showed a strong nuclear p53 staining in most malignant cells.

CORRELATION BETWEEN MICROSATELLITE

INSTABILITY AND p53 MUTATION

The correlation between microsatellite instability and p53 mutation was also analysed for patients with MALT or SMZL in which both studies were performed. There was a single patient (with a gastric large B cell lymphoma) in whom simultaneous p53 mutation and microsatellite instability were found. Other patients showed either p53 mutation (two patients), or microsatellite instability (four patients). There was no significant correlation between microsatellite instability and p53 mutation $(\mathrm{p}>0.05)$.

\section{Discussion}

The data obtained in our study show that microsatellite instability is absent from all the patients with SMZL studied. In contrast, a quarter of the patients with MALT lymphomas had microsatellite instability. No differences were found with respect to the frequency of p53 mutations.

The overall frequency of microsatellite instability in lymphoid disorders seems to be strikingly low. When using a restrictive definition of microsatellite instability (abnormalities at more than one locus) it seems that the only lymphoid tumours where microsatellite instability is found are MALT lymphomas, as these data confirm. Thus, Peng described a frequency of 21 of 40 MALT lymphomas with microsatellite instability (alterations in two or more microsatellites). ${ }^{31}$ The data on nonHodgkin's lymphoma in HIV positive patients are not so conclusive because, although microsatellite instability was found in three of six patients by Bedi et $a l,{ }^{47}$ it was present in only one of 17 patients in the series of Gamberi et 
$a l .{ }^{25}$ The data obtained on other types of lymphoma show a rare or undetectable frequency of microsatellite instability. ${ }^{25-27} 48$ Thus, it has also been found in cases of Kaposi's sarcoma associated herpes virus positive primary effusion lymphoma, ${ }^{49}$ and post-transplant lymphoproliferative disorders. ${ }^{50}$ In contrast with this finding, research into hepatitis $\mathrm{C}$ virus associated lymphoma has not shown microsatellite instability to be present. ${ }^{48}$

The role of microsatellite instability in neoplastic transformation has been the subject of recent investigations. Microsatellite instability has been implicated as a pathogenetic mechanism in subsets of tumours linked pathogenically to chronic infection and inflammation, such as tumours occurring after schistosomiasis, viral hepatitis $\mathrm{B}$, chronic ulcerative colitis, or papillomavirus infection. ${ }^{51-54}$ This relation between neoplasia, microsatellite instability, and a chronic stimulus has been proposed for MALT lymphomas, and Helicobacter pylori has been suggested to be the infectious agent. ${ }^{31}$ The findings of this series in SMZL suggest (keeping in mind the limitation of the number of cases studied and the choice of the microsatellites) that microsatellite instability does not play a role in the pathogenesis of lymphomas of this type, unlike has been found in MALT lymphomas.

p53 mutation is a relatively infrequent phenomenon in lymphoid tumours, in comparison with tumours of other cell lineages. ${ }^{55}$ However, data have been presented which suggest that this genetic abnormality could be remarkably frequent in MALT lymphoma (24.3-27.5\%; both series coming from the same group), and might be associated with tumour progression. ${ }^{3156} \mathrm{~A}$ report by Baldini et al also showed a high frequency of p53 mutations in SMZL (six of 15). Other studies have failed to reach firm conclusions, mainly because of the small sizes of the samples analysed. ${ }^{37} 3857$ The frequencies of p53 mutation seen in our study are similar to those seen in other low grade non-Hodgkin's lymphoma subtypes. ${ }^{33}$ This observation does not support the hypothesis that p53 mutation is frequent in these tumours, or that it could help in differentiating SMZL from MALT lymphomas. The discrepancies with the other studies published to date could be a result of differences in the size of samples, or the sensitivity of the technique used in our study (PCR-SSCP, 10\%; data not published). Further studies are needed to confirm and clarify these discrepancies.

In most non-lymphoid tumours, it seems that microsatellite instability and p53 mutations are present as alternative genetic events, and are rarely present simultaneously. ${ }^{35}{ }^{36}$ Our data do not show any significant correlation between microsatellite instability and p53 mutations in lymphomas.

Our data indicate some differences between SMZL and MALT lymphomas, adding to recent observations that raise doubts about whether SMZL has a cellular origin in the marginal zone compartment of the spleen. Further studies are needed to illustrate phenotypic or molecular markers of marginal zone lineage origin in splenic lymphomas.
The authors thank Drs T Flores, L Bernardo, and P Gonzalvo from the Pathology Departments at hospitals in Salamanca, Gerona, and Asturias, respectively, for kindly providing the patients in this series and D Oterino for statistical analysis. This study was supported by a grant (96/1382) from the Fondo de Investigaciones Sanitarias, Ministerio de Sanidad y Consumo, Spain.

1 Harris NL, Jaffe NS, Stein H, et al. A revised EuropeanAmerican classification of lymphoid neoplasms: a proposal from the international lymphoma study group. Blood 1994;84:1361-92.

2 Schmid C, Kirkham N, Diss T, et al. Splenic marginal zone lymphoma. Am F Surg Pathol 1992;16:455-66.

3 Hollema H, Visser L, Poppema S. Small lymphocytic ymphomas with predominant splenomegaly: a comparison of immunophenotypes with cases of predominant lymphadenopathy. Mod Pathol 1991;4:712-17.

4 Dierlamm J, Pittaluga S, Wlodarska I, et al. Marginal zoneB-cell lymphomas of different sites share similar cytogenetic and morphologic features. Blood 1996;87:299-307.

Dierlamm J, Michaux L, Wlodarska I, et al. Trisomy 3 in marginal zone B-cell lymphoma: a study based on Bytogenetic analysis and fluores

6 Sole F, Woessner S, Florensa L, et al. Frequent involvement of chromosomes $1,3,7$ and 8 in splenic marginal zone of chromosomes 1, 3, 7 and 8 in splenic marg
B-cell lymphoma. Br $\mathcal{F}$ Haematol 1998;98:446-9.

7 Brynes RK, Almaguer P, Leathery KE, et al. Numerical cytogenetic abnormalities of chromosomes 3,7 , and 12 in marginal zone B-cell lymphomas. Mod Pathol 1996;9:9951000

8 Wotherspoon AC, Finn TM, Isaacson PG. Trisomy 3 in low-grade B-cell lymphomas of mucosa-associated lymphoid tissue. Blood 1995;85:2000-4.

9 Mollejo M, Menarguez J, Lloret E, et al. Splenic marginal zone lymphoma: a distinctive type of low-grade B-cell ymphoma. A clinicopathological study of 13 cases. Am 7 Surg Pathol 1995;19:1146-57.

10 Hammer RD, Glick AD, Greer JP, et al. Splenic marginal zone lymphoma. A distinct B-cell neoplasm. Am $\mathcal{F}$ Surg Pathol 1996;20:613-26.

11 Isaacson PG, Piris MA. Splenic marginal zone lymphoma. Adv Anat Pathol 1997;4:191-201.

12 Wooster R, Cleton-Jansen AM, Collins N, et al. Instability of short tandem repeats (microsatellite) in human cancer. Nat Genet 1994:6:152-6.

13 Ionov Y, Peinado MA, Malkhosyan S, et al. Ubiquitous somatic mutations in simple repeated sequences reveal a new mechanism of colonic carcinogenesis. Nature 1993; 363:558-6.

14 Aaltonen LA, Pelmomanki P, Leach FS, et al. Clues to the pathogenesis of familial colorectal cancer. Science 1993; 260:812-16.

15 Peltomanki P, Lothe RA, Aaltonen LA, et al. Microsatellite instability is associated with tumours that characterize the hereditary non-polyposis colorectal carcinoma syndrome. Cancer Res 1993;53:5853-5.

16 Thibodeau SN, Bren G, Schaid B. Microsatellite instability in cancer of the proximal colon. Science 1993;260:816-19.

17 Fishel R, Lescoe MK, Rao MRS, et al. The human mutator gene homolog MSH2 and its association with hereditary gene homolog MSH2 and its association with he

18 Bronpolyposis Colon cancer. Cell 1993, Baker SM, Morrison PT, et al. Mutation in the DNA mismatch repair gene homologue hMLH1 is associated with hereditary non-polyposis colon cancer. Nature 994;368:258-61.

19 Nicolaides NC, Papadopoulos N, Liu B, et al. Mutations of two PMS homologues in hereditary nonpolyposis colon cancer. Nature 1994;371:75-80.

20 Leach FS, Nicolaides NC, Papadopoulos N, et al. Mutations of a MutS homolog in hereditary nonpolyposis colorectal cancer. Cell 1993;75:1215-25.

21 Papadopoulos N, Nicolaides NC, Wei YF, et al. Mutation of a MutL homolog in hereditary colon cancer. Science 1994; 263:1625-9.

22 Rhyu MG, Park WS, Meltzer SJ. Microsatellite instability occurs frequently in human gastric carcinoma. Oncogene 1994;9:29-32.

23 Merlo A, Mabry M, Gabrielson E, et al. Frequent microsatellite instability in primary small cell lung cancer. Cancer Res 1993;53:5849-52.

24 Mao L, Cchoenberg MP, Scicchitano M, et al. Molecular detection of primary bladder cancer by microsatellite detection of primary bladder

25 Gamberi B, Gaidano G, Parsa N, et al. Microsatellite instability is rare in B-cell non-Hodgkin's lymphomas. Blood 1997;89:975-9

26 Randerson J, Cawkwell L, Jack A, et al. Microsatellite instability in follicle centre cell lymphoma. Br F Haematol 1996; 93:160-2.

27 Robledo M, Martinez B, Arranz E, et al. Genetic instability of microsatellite in hematological neoplasms. Leukemia 1995;9:960-4

28 Volpe G, Gamberi B, Pastore C, et al. Analysis of microsatellite instability in chronic lymphoproliferative disorders. Ann Hematol 1996;72:67-71.

29 Pabst T, Schwaller J, Bellomo MJ, et al. Frequent clonal loss of heterozygosity but scarcity of microsatellite instability at chromosomal breakpoint cluster regions in adult leukemias. Blood 1996;88:1026-34.

30 Gartenhaus R, Johns MM 3rd, Wang P, et al. Mutator phenotype a subset of chronic lymphocytic leukemia. Blood 1996;87:38-41. 
31 Peng $\mathrm{H}$, Chen G, Du M, et al. Replication error phenotype and p53 gene mutation in lymphomas of mucosaassociated lymphoid tissue. Am f Pathol 1996;148:643-8.
Hollstein M, Sidranky D, Vogelstein B, et al. 53 mutations in human cancers. Science 1991;253:49-53.

33 Wada M, Bartram CR, Nakamura H, et al. Analysis of p53 mutations in a large series of lymphoid hematologic malig nancies of childhood. Blood 1993;82:3163-9.

34 Gaidano G, Ballerini P, Gong JZ, et al. p53 mutations in human lymphoid malignancies: association with Burkit lymphoma and chronic lymphocytic leukaemia. Proc Nat Acad Sci USA 1991;88:5413-17.

35 Cottu PH, Muzeau F, Estreicher A, et al. Inverse correlation between RER+ status and p 53 mutation in colorectal cancer cell lines. Oncogene 1996;13:2727-30.

36 Renault B, Calistri, Buonsanti G, et al. Microsatellite instability and mutations of p53 and TGF-beta RII genes in gastric cancer. Hum Genet 1996;98:601-7.

37 Villuendas R, Piris MA, Algara P, et al. The expression of p53 protein in non-Hodgkin's lymphomas in not always p53 protein in non-Hodgkin's lymphomas in not always

38 Wu CD, Jackson CL, Medeiros LJ. Splenic marginal zone lymphoma: an immunophenotypic and molecular study of (995:8:124A

39 Baldini L, Fracchiolla NS, Cro, LM, et al. Frequent p53 gene involvement in splenic B-cell leukemia/lymphomas of possible marginal zone origin. Blood 1994;84:270-8.

40 Isaacson PG, Matutes E, Burke M, et al. The histopathology of splenic marginal lymphoma with villous lymphocytes. Blood 1994;84:3828-34

41 Mollejo M, Lloret E, Menarguez J, et al. Lymph node involvement by splenic marginal zone lymphoma morphological and immunohistochemical features. Am 7 Surg Pathol 1997;21:772-80.

42 Viluendas R, Piris MA, Orradre JL, et al. Different bcl-2 protein expression in high-grade B-cell lymphomas derived from lymph node or mucosa-associated lymphoid tissue. Am F Pathol 1991;139:989-93.

43 Fey MF, Pilkington SP, Summers P, et al. Molecular diagnosis of haematological disorders using DNA from stored sis of haematological disorders using DNA from

44 Villuendas R, Pezella F, Gatter K, et al. p21 WAF1/ CIP1 and MDM2 expression in non-Hodgkin's lymphoma and their relationship to p53 status: a p53+, MDM2-, p21immunophenotype associated with missense p53 mutations. F Pathol 1997;181:51-61
45 Mao L, Lee DJ, Tockman MS, et al. Microsatellite alterations as clonal markers for the detection of human cancer. Proc Natl Acad Sci USA 1994;91:9871-5.

46 WeberJL, Wong C. Mutations of human short tandem repeats. Hum Mol Genet 1993;2:1123-8.

47 Bedi GC, Westra WH, Farzadegan H, et al. Microsatellite instability in primary neoplasms from HIV+ patients. Nat Med 1995;1:65-8.

48 De Vita S, Gasparotto D, Pivetta B, et al. Rarity of microsatellite genomic instability in B cell non-Hodgkin's lymphomas in hepatitis C virus-infected patients. Br $\mathrm{f}$ Haematol 1997;97:463-5.

49 Gaidano G, Pastore C, Gloghini A, et al. Microsatellite instability in $\mathrm{KSVH} / \mathrm{HHV}-8$ positive body-cavity-based lymphoma. Hum Pathol 1997;28:748-50.

50 Larso RS, Scott MA, McCurley TL, et al. Microsatellite analysis of posttransplant lymphoproliferative disorders: determination of donor/recipient origin and identification of putative lymphomagenic mechanism. Cancer Res 1996; 56:4378-81.

51 Rosin MP, Anwar WA, Ward AJ. Inflammation, chromosomal instability, and cancer: the schistosomiasis model. Cancer Res 1994;54:1929-33.

52 Salvucci M, Lemoine A, Azoulay D, et al. Frequent microsatellite instability in post hepatitis B viral cirrhosis. Oncogene 1996;13:2681-5.

53 Brentnall TA, Crispin DA, Bronner MP, et al. Microsatellite instability in non-neoplastic mucosa from patients with chronic ulcerative colitis. Cancer Res 1996;56:1237-40.

54 Kisseljov F, Semionova L, Samoylova E, et al. Instability of chromosome 6 microsatellite repeats in human cervical tumours carrying papillomavirus sequences. Int 7 Cancer 1996;69:484-97.

55 Nigro JM, Baker SJ, Preisinger AC, et al. Mutations in the p53 gene occur in diverse human tumour types. Nature 1989;342:705-7.

$56 \mathrm{Du} \mathrm{M}$, Peng H, Singh N, et al. The accumulation of p53 abnormalities is associated with progression of mucosaassociated lymphoid tissue lymphoma. Blood 1995;86: 4587-93.

57 Levy V, Miller C, Koeffler P, et al. p53 in lymphomas of mucosal-associated lymphoid tissues. Mod Pathol 1996;9: 245-8. 